\title{
DETERMINAN KREDIT BERMASALAH PADA BANK DEVISA DI INDONESIA
}

\author{
Oleh \\ Evi Sistiyarini \\ Fakultas Ekonomi dan Bisnis Universitas Hayam Wuruk Perbanas \\ (d/h STIE Perbanas Surabaya) \\ Email : evi.sistiyarini@perbanas.ac.id \\ Ririn Poerwanti \\ Fakultas Ekonomi dan Bisnis Universitas Hayam Wuruk Perbanas \\ (d/h STIE Perbanas Surabaya) \\ Email : ririn@perbanas.ac.id \\ *Korespodensi: Email penulis pertama
}

\begin{tabular}{l}
\hline Article Info \\
\hline Article History : \\
Received 29 August - 2021 \\
Accepted 06 Sept - 2021 \\
Available Online 25 Sept- \\
2021
\end{tabular}

Keyword:

Foreign exchange bank,

Panel Data, Regression,

Problem Credit

\section{PENDAHULUAN}

Salah satu tugas bank adalah memberikan pinjaman kepada masyarakat. Di dalam kegiatan penyaluran kredit, ada keuntungan yang diperoleh bank dalam bentuk pendapatan bunga dimana pendapatan bunga merupakan pendapatan terbesar bagi bank. Akan tetapi, penyaluran kredit bank kepada nasabah juga memiliki risiko yaitu risiko kredit bermasalah. Tingginya kredit bermasalah yang dimiliki oleh suatu bank dapat berdampak kepada tingkat Kesehatan bank tersebut. Semakin baik kualitas kredit bank mengindikasikan bahwa bank masih dikategorikan sebagai bank yang sehat. Terjadinya kredit bermasalah juga dapat merugikan bank.

Kredit bermasalah merupakan kredit yang mengalami penundaan pembayaran oleh debitur. Peningkatan kredit bermasalah bank berdampak pada peningkatan rasio NPL (Non Performing Loan) yaitu rasio antara jumlah kredit bermasalah dengan total kredit bank (Ulfa, 2017). Peningkatan NPL menunjukkan peningkatan tingkat kredit bermasalah bank dan dapat memberikan pengaruh negatif bagi bank (Akbar, Taufik dkk, 2018). Peningkatan NPL pada bank 
dapat menggangu likuiditas bank (Prihatin, Lilik et al, 2018). Bank Indonesia telah mensyaratkan bahwa bank tingkat NPL suatu bank adalah di bawah 5\%.

Berdasarkan data laporan keuangan bank dapat diketahui bahwa dari 44 bank devisa di Indonesia hanya terdapat 6 bank yang mengalami rata-rata trend negatif yang berarti 6 bank tersebut mengalami penurunan kredit/pembiayaan bermasalah, sedangkan sisanya sebanyak 38 bank mengalami peningkatan kredit bermasalah. Hal ini mengindikasikan bahwa masih banyak bank devisa di Indonesia yang mengalami peningkatan kredit bermasalah. Rata-rata trend keseluruhan kredit bermasalah bank devisa selama periode penelitian meningkat sebesar 0,26 persen.

Terjadinya kredit bermasalah bank dapat disebabkan karena faktor yang berasal dari dalam bank seperti Capital Adequacy Ratio (CAR), Loan to Deposit Ratio (LDR), Net Interest Margin (NIM) \& Biaya Operasional terhadap Pendapatan Operasional (BOPO). Selain itu, kredit bermasalah juga dapat disebabkan karena faktor yang berasal dari luar seperti tingka suku bunga dan inflasi.

CAR merupakan rasio permodalan bank. Peningkatan CAR menunjukkan permodalan yang baik. Modal bagi bank dapat digunakan untuk mengcover risiko salah satu nya adalah risiko kredit. Kamaludin, et al (2015) membuktikan adanya pengaruh negatif signifikan antara CAR terhadap NPL. Semakin tinggi modal yang dimiliki bank, semakin baik kemampuan bank dalam mengcover risiko sehingga kredit bermasalah bank yang ditunjukkan dengan NPL juga semakin rendah. Akan tetapi Halim, Marisya (2015) serta Handayani dan Bambang (2017) yang justru menemukan bahwa tidak adanya pengaruh CAR terhadap NPL. Hal ini dikarenakan rata-rata CAR bank di atas $8 \%$ membuat bank yakin untuk memberikan kredit yang lebih berkualitas. Alexandri dan Teguh (2015) juga membuktikan bahwa CAR berpengaruh positif tidak signifikan terhadap NPL. Andreani dan Erick (2016) membuktikan hasil yang berbeda bahwa CAR berpengaruh negatif tidak signifikan terhadap NPL. Penurunan NPL terjadi karena kemampuan bank dalam menanggung risiko yang semakin baik.

LDR menunjukkan jumlah penyaluran kredit bank kepada debitur berdasarkan pada sumber dana yang dimiliki oleh bank (Astrini et al, 2018). Tingginya jumlah kredit yang disalurkan akan berdampak pada tingginya risiko kredit bermasalah bank jika bank tidak mampu mengelola kredit tersebut dengan baik. Prinsip kehati-hatian perlu diterapkan oleh bank dalam memberikan fasilitas kredit dengan memperhatikan analisis kredit yang tepat. Penelitian Firmansyah, Irman (2014), Kamaludin, et al (2015), Andreani dan Erick (2016), Handayani dan Bambang (2017) memberi bukti bahwa terdapat pengaruh positif signifikan antara LDR terhadap NPL. Halim, Handayani (2015) membuktikan pengaruh positif tidak signifikan antara LDR terhadap NPL.

NIM merupakan rasio bank dalam menghasilkan pendapatan bunga bersih dari aktiva produktif yang dimilikinya (Ginting dan Mulyo, 2016). Semakin tinggi NIM berarti semakin tinggi pendapatan bunga bersih yang diterima oleh bank, artinya semakin baik kemampuan bank dalam mengelola aset produktif nya sehingga kredit bermasalah yang ditunjukkan dengan rasio NPL akan semakin menurun. Kamaludin, et al (2015) membuktikan NIM tidak berpengaruh terhadap NPL. Penelitian lain oleh Andreani dan Erick (2016) yang menunjukkan NIM berpengaruh positif signifikan terhadap NPL.

Rasio BOPO merupakan rasio antara jumlah beban operasional dan pendapatan operasional bank. Rasio BOPO yang semakin tinggi mengindikasikan kondisi yang kurang baik karena peningkatan beban operasional yang lebih tinggi dibandingkan peningkatan pendapatan operasional. Tingginya beban operasional mengindikasikan bahwa bank semakin tidak efisien dan dapat menurunkan laba. Ketidakefisienan bank dalam kegiatan operasionalnya, dapat dapat meningkatkan jumlah kredit bermasalah dan NPL juga meningkat. Andreani dan Erick (2016) membuktikan bahwa BOPO berpengaruh positif signifikan terhadap NPL.

Tingkat suku bunga berdampak positif terhadap NPL. Tingginya suku bunga akan berdampak pada meningkatnya bunga 
simpanan maupun pinjaman. Semakin tinggi bunga pinjaman maka semakin sulit nasabah dalam membayar kewajiban kepada bank. Hal ini berdampak pada semakin tinggi kredit bermasalah dan menyebabkan NPL meningkat. Skenderi et al (2016), Andreani dan Erick (2016) membuktikan bahwa tingkat suku bunga berpengaruh positif signifikan terhadap NPL. Hal ini tidak sejalan dengan Kamaludin, et al (2015) yang membuktikan adanya pengaruh positif tidak signifikan antara suku bunga terhadap NPL.

Terjadinya inflasi di suatu negara dapat berdampak pada peningkatan harga barang secara keseluruhan. Naiknya harga barang secara terus menerus dapat menyebabkan kesulitan pembayaran pinjaman oleh debitur. Hal ini berdampak pada meningkatnya kredit bermasalah bank sehingga NPL juga ikut meningkat. Firmansyah, Irman (2014) membuktikan bahwa inflasi berpengaruh negatif signifikan terhadap NPF bank syariah di Indonesia. Penelitian tersebut sejalan dengan penelitian Andreani dan Erick (2016) bahwa inflasi berpengaruh negatif signifikan terhadap NPL. Kamaludin, et al (2015), Alexandri dan Teguh (2015) membuktikan bahwa inflasi berpengaruh positif tidak signifikan terhadap NPL. Halim, Marisya(2015) juga memberikan bukti yang berbeda bahwa inflasi justru tidak berpengaruh terhadap NPL.

Berdasarkan permasalahan di atas mengenai adanya peningkatan kredit bermasalah serta hasil dari beberapa penelitian terdahulu tentang kredit bermasalah yang memberikan hasil yang tidak konsisten sehingga hal ini menjadi research gap untuk melakukan penelitian lebih lanjut tentang determinan kredit bermasalah pada bank devisa di Indonesia.

\section{KAJIAN PUSTAKA DAN PENGEMBANGAN HIPOTESIS}

Messai and Jouini (2013) dalam penelitiannya menemukan bahwa GDP, ROA, memiliki pengaruh negatif signifikan terhadap NPL. Variabel IRR, loans losses reserves memiliki pengaruh positif signifikan terhadap NPL.

Firmansyah, Irman (2014) meneliti tentang determinan pembiayaan bermasalah pada bank syariah di Indonesia. Hasil penelitian menunjukkan bahwa ukuran bank, BOPO tidak berpengaruh terhadap NPF. Variabel GDP, inflasi berpengaruh negatif signifikan terhadap NPF bank syariah. Variabel FDR memiliki pengaruh positif signifikan terhadap NPF.

Kamaludin dkk (2015) meneliti tentang determinan NPL pada industri perbankan yang go public. Hasil penelitian menunjukkan bahwa LDR dan nilai tukar berpengaruh positif signifikan terhadap NPL. Inflasi dan tingkat suku bunga berpengaruh positif tidak signifikan terhadap NPL. CAR berpengaruh negatif signifikan terhadap NPL, sedangkan NIM tidak berpengaruh terhadp NPL.

Halim, Marisya(2015) melakukan penelitian tentang faktor dari dalam dan faktor dari luar bank yang berpengaruh pada Non Performing Loan di bank pemerintah dan bank swasta di Jawa Timur. Penelitian ini menggunakan regresi data panel dalam pengolahan data. Hasil penelitian menunjukkan bahwa CAR, inflasi, nilai tukar, dan PDRB tidak berpengaruh terhadap NPL. Rasio LDR berpengaruh positif tidak signifikan terhadap NPL.

Alexandri dan Teguh (2015) meneliti tentang Faktor internal dan eksternal yang mempengaruhi NPL. Kesimpulan penelitian menunjukkan bahwa ukuran bank, GDP memiliki pengaruh negatif tidak signfikan terhadap NPL. Variabel CAR memiliki pengaruh positif tidak signifikan terhadap NPL. ROA memiliki pengaruh positif signfikan terhadap NPL. Sedangkan variable inflasi memiliki pengaruh positif tidak signifikan.

Skenderi et al (2016) membuktikan bahwa variable GDP, maturity dan grace apply memmiliki pengaruh negatife terhadap NPL. Terdapat pengaruh positif antara tingkat suku bunga, tingkat inflasi dan tingkat pengangguran terhadap NPL.

\section{Kolektibilitas Kredit}

Dalam SEBI No 73/DPNP Tahun 2005 terdapat 5 kriteria kredit yaitu Lancar (pembayaran tepat waktu), Dalam Perhatian Khusus (terjadi tunggakan penundaan pembayaran sampai dengan 3 bulan.), Kurang Lancar (terjadi penundaan pembayaran sampai 4 bulan), Diragukan (terjadi penundaan pembayaran sampai 6 
bulan) dan Macet (terjadi penundaan pembayaran lebih dari 6 bulan). Kualitas kredit dikatakan sebagai kredit bermasalah jika masuk dalam kelompok Kurang lancar, diragukan dan macet. Soedarsa, Herry dan Apri Irianti (2015) menjelaskan bahwa upaya penyelamatan kredit bermasalah ini dapat menggunakan cara rescheduling (penjadwalan ulang), restructuring (penataan kembali), dan reconditioning (persyaratan ulang).

\section{NPL}

NPL adalah rasio yang mencerminkan ketidakmampuan debitur dalam membayar pinjaman kepada bank (Dwihandayani, Deasy, 2017). Semakin tinggi nilai NPL berarti semakin meningkat kredit bermasalah bank. Hal ini menunjukkan ketidakmampuan bank dalam pengelolaan kredit. Berikut ini adalah cara perhitungan NPL (Ikatan Bankir Indonesia, 2013: 177).

$$
\text { NPL }=\frac{\text { Kredit bermasalah }}{\text { Total Kredit }}
$$

\section{Pengaruh Antar Variabel \\ Pengaruh CAR Terhadap NPL}

CAR sebagai rasio kecukupan modal yang digunakan untuk mendukung operasional bank (Fauzi, Achmad dkk, 2020). CAR memiliki pengaruh negatif terhadap NPL. Semakin tinggi CAR, menunjukkan bahwa kemampuan permodalan bank semakin baik dan semakin mampu bank tersebut dalam mengcover terjadinya risiko sehingga adanya kredit bermasalah bank semakin menurun. Hal ini menyebabkan rasio NPL bank semakin menurun. Rumus CAR adalah sebagai berikut (Ikatan Bankir Indonesia, 2013: 174).

\section{$\mathrm{CAR}=\frac{\text { Modal }}{\text { Aktiva Tertimbang menurut Risiko }}$}

H1 : CAR berpengaruh negatif signifikan terhadap NPL pada bank devisa di Indonesia

\section{Pengaruh LDR Terhadap NPL}

LDR menunjukkan banyaknya kredit yang disalurkan oleh bank kepada debitur atas sumber dana bank (Astrini et al, 2018). LDR berpengaruh positif terhadap NPL. Semakin tinggi LDR menunjukkan kemampuan likuiditas bank yang cukup baik. Tingginya jumlah kredit yang disalurkan kepada nasabah tanpa adanya pengelolaan dan analisis yang baik dapat meningkatkan risiko terjadinya kredit bermasalah. Peningkatan kredit bermasalah bank dapat meningkatkan rasio NPL bank. Rumus LDR adalah:

$$
\text { LDR }=\frac{\text { Total kredit }}{\text { Dana Pihak Ketiga }}
$$

H2 : LDR berpengaruh positif signifikan terhadap terhadap NPL pada bank devisa di Indonesia.

\section{Pengaruh NIM Terhadap NPL}

NIM merupakan rasio yang menunjukkan kemampuan bank dalam menghasilkan pendapatan bunga bersih dari aktiva produktif yang dimilikinya (Ginting dan Mulyo, 2016). NIM berpengaruh negatif terhadap NPL. Peningkatan NIM mengindikasikan efektifitas kredit bank sebagai aktiva produktif sehingga kredit bermasalah semakin rendah dan NPL juga semakin rendah. Penurunan NIM pada bank dapat mengindikasikan semakin tingginya kredit bermasalah sehingga NPL semakin besar. NIM dapat dihitung dengan cara sebagai berikut (Ikatan Bankir Indonesia, 2013: 179).

$\mathrm{NIM}=\frac{\text { Pendapatan Bunga Bersih }}{\text { Rata }- \text { rata aset produktif }}$

H3 : NIM berpengaruh negatif signifikan terhadap NPL pada bank devisa di Indonesia.

\section{Pengaruh BOPO terhadap NPL}

BOPO merupakan rasio efisiensi bank yang dihitung dari perbandingan antara beban operasional (beban bunga dan beban operasional lain) dan pendapatan operasional (pendapatan bunga dan pendapatan operasional lain) (Karim, Abdul dan Fifi Hanafia, 2020). BOPO berpengaruh positif terhadap NPL. Semakin besar BOPO maka 
kondisi bank semakin kurang efisien karena semakin tinggi beban yang dikeluarkan oleh bank dibandingkan dengan pendapatan yang diterima. Peningkatan pendapatan bunga yang lebih kecil mengindikasikan bahwa kemampuan membayar pinjaman debitur yang semakin rendah sehingga rasio kredit bermasalahnya (NPL) semakin tinggi. BOPO dapat diukur dengan cara sebagai berikut (Ikatan Bankir Indonesia, 2013: 179).

$$
\text { BOPO }=\frac{\text { Beban Operasional }}{\text { Pendapatan Operasional }}
$$

H4 : BOPO berpengaruh positif signifikan terhadap NPL pada bank devisa di Indonesia.

\section{Pengaruh Suku Bunga terhadap NPL}

Suku bunga berpengaruh positif terhadap NPL. Peningkatan suku bunga SBI dapat mengakibatkan peningkatan bunga simpanan. Hal ini dapat menyebabkan peningkatan biaya yang dikeluarkan bank. Jika dikaitkan dengan suku bunga pinjaman, peningkatan suku bunga pinjaman menyebabkan debitur semakin sulit untuk memenuhi kewajibannya kepada bank berupa pembayaran angsuran. Hal ini berdampak pada semakin tingginya kredit bermasalah bank yang ditunjukkan dengan semakin tingginya rasio NPL. Tingkat suku bunga menggunakan JIBOR dari Bank Indonesia. Pertiwi, Risna et al (2020) menemukan bahwa tingkat suku bunga berpengaruh positif signifikan terhadap pembiayan bermasalah

H5 : Tingkat suku bunga secara parsial berpengaruh positif signifikan terhadap NPL pada bank devisa di Indonesia.

\section{Pengaruh Inflasi Terhadap NPL}

Terjadinya inflasi dari luar negeri dapat menyebabkan kenaikan harga barang secara terus menerus di dalam negeri (Linda, Muthia et al, 2015). Inflasi berpengaruh positif terhadap NPL Tingginya tingkat inflasi dapat menurunkan pendapatan riil masyarakat, sehingga kemampuan masyarakat dalam membeli barang menjadi menurun dan standar hidup masyarakat juga mengalami penurunan. Kondisi ini juga menyebabkan terjadinya ketidakmampuan debitur untuk membayar kewajibannya. Peningkatan kesulitan pembayaran yang dialami oleh debitur ini dapat meningkatkan rasio NPL Bank. Tingkat Inflasi diukur dengan menghitung CPI.

H6 : Tingkat inflasi secara parsial berpengaruh positif signifikan terhadap NPL pada bank devisa di Indonesia.

\section{METODE PENELITIAN}

Penelitian ini merupakan explanatory research karena penelitian ini bertujuan untuk menguji hipotesis antara variabel bebas dengan variabel terikat (Agustina, W \& Surachim, 2017). Sumber data sekunder berasal dari publikasi laporan keuangan bank. Teknik pengumpulan data yaitu teknik dokumentasi. Pengumpulan data diperoleh dengan mendowload data data di laporan keuangan bank yang ada di website Otoritas Jasa Keuangan (OJK) maupun di website masing-masing bank. Populasi penelitian meliputi seluruh bank devisa di Indonesia. Teknik pengambilan sampel secara purposive sampling yaitu Teknik pengambilan sampel dengan menggunakan kriteria tertentu (Sugiyono, 2012:126). Kriteria tersebut yaitu bank merupakan Bank devisa konvensional serta Bank yang secara rutin menyampaikan laporan keuangan selama periode penelitian yaitu Triwulan I tahun 2013 sampai dengan triwulan IV Tahun 2017. Dari kriteria tersebut diperoleh sampel sebanyak 33 bank.

Variabel dependen menggunakan variabel NPL. variabel independen terdiri dari variabel CAR, LDR, NIM, BOPO, tingkat suku bunga dan tingkat inflasi. Teknik analisis data menggunakan regresi data panel. Teknik analisis data pada penelitian ini adalah menggunakan regresi data panel yang merupakan kombinasi antara data time series dan data cross section. Nuryanto dan Zulfikar Bagus Pambuko (2018:83-97) menjelaskan bahwa terdapat 3 model yang ada pada regresi data panel yaitu pooled least square model (PLS), fixed effect model (FEM) serta random effect model (REM). Untuk memilih salah satu dari ketiga model tersebut, maka dapat digunakan pengujian model yaitu Chow Test dan Hausman Test. Chow Test digunakan untuk menentukan model yang paling layak antara 
FEM dan PLS. Jika nilai F statistik lebih besar dari $\mathrm{F}$ tabel maka FEM merupakan model yang lebih baik. Hausman Test digunakan untuk menentukan antara model FEM dan REM. Jika nilai statistik Hausman lebih besar dari dari nilai tabel, maka FEM merupakan model yang lebih baik. Uji statistik dilakukan dengan cara menguji uji $\mathrm{F}$ dan uji t.

\section{HASIL DAN PEMBAHASAN Model Regresi Data Panel}

Pemilihan ketiga model regresi menggunakan uji chow tes, uji hausman tes dan uji lagrange multiplier.

\section{Uji Chow Test}

Tabel 1. Hasil Uji Chow Test

\begin{tabular}{lccc}
\multicolumn{1}{c}{$\begin{array}{c}\text { Effect } \\
\text { Test }\end{array}$} & Statistic & d.f & Prob \\
\hline $\begin{array}{l}\text { Cross } \\
\text { Section F }\end{array}$ & 14.320308 & $(32,621)$ & 0.0000 \\
Cross & 364.775683 & & 0.0000 \\
Section & & 32 & \\
Chi & & & \\
Square & & & \\
\hline
\end{tabular}

Sumber: Data diolah, 2018

Tabel 1 membuktikan nilai $\mathrm{F}$ hitung 14,320308 di atas $F$ tabel 2,112446 dengan probabilitas signifikansi sebesar 0,0000 di bawah $\alpha 0,05$. Hasil tersebut membuktikan FEM merupakan model yang lebih baik daripada CEM.

\section{Uji Hausman Test}

\begin{tabular}{|c|c|c|c|}
\hline \multicolumn{4}{|c|}{ Tabel 2. Hasil Uji Hausman Tes } \\
\hline $\begin{array}{c}\text { Test } \\
\text { Summamry }\end{array}$ & $\begin{array}{c}\text { Chi-Sq } \\
\text { Statistic }\end{array}$ & $\begin{array}{c}\text { Chi- } \\
\text { Sq.d.f }\end{array}$ & Prob \\
\hline $\begin{array}{l}\text { Cross } \\
\text { Section } \\
\text { random }\end{array}$ & 0.000000 & 6 & 1.0000 \\
\hline
\end{tabular}

Sumber : Data Diolah, 2018

Hasil hausman test membuktikan nilai statistik Hausman 0,0000 lebih rendah dari nilai tabel 719,8304. Selain itu nilai signifikansi 1,000 di atas $\alpha$ 0,05. Hasil tersebut mengindikasikan REM merupakan model yang lebih baik.

\section{Uji Lagrange Multiplier}

Hasil chow test dan hausman test menghasilkan ketepatan model yang tiadak konsiten sehingga perluu dilakukan uji lagrange multiplier. Nilai LM pada hitung data panel sebesar 141,672 di atas $\alpha 0,05$. Model REM merupakan model yang lebih tepat daripada CEM. Berdasarkan hasil ketiga uji tersebut, REM merupakan model yang dipilih dalam penelitian ini.

Tabel 3. Hasil Model Random Effect

Model

\begin{tabular}{lllll}
\hline Variable & Coefficient & Std.Error & $\begin{array}{c}\text { t- } \\
\text { Statistic }\end{array}$ & Prob \\
\hline CAR & $-8.61 \mathrm{E}-05$ & 0.000439 & - & 0.8447 \\
LDR & -0.004049 & 0.003577 & - & 0.2580 \\
& & & 1.132046 & \\
NIM & 0.003981 & 0.050077 & 0.079500 & 0.9367 \\
BOPO & $-2.21 \mathrm{E}-05$ & 0.000106 & - & 0.8359 \\
BUNGA & 0.116706 & 0.0053782 & 2.169982 & 0.0304 \\
INFLASI & -0.210079 & 0.020738 & - & 0.0000 \\
& & & 10.12998 & \\
C & 2.246874 & 0.538390 & 4.173318 & 0.0000 \\
\hline
\end{tabular}

Sumber: Data diolah, 2018

Persamaan Regresi Data Panel

$\mathrm{NPL}=-8.61 \mathrm{e}-05^{*} \mathrm{CAR}-0.004049^{*} \mathrm{LDR}+$ $0.003981 * \mathrm{NIM}-2.21 \mathrm{e}-05 * \mathrm{BOPO}+$ $0.116706 *$ BUNGA $-0.210079 *$ INFLASI + $2.246874+[\mathrm{CX}=\mathrm{R}]$

a) $\alpha=2.246874$, jika nilai variabel yang lain konstan maka nilai variabel Y (NPL) adalah sebesar 2.246874

b) $\beta_{1}=-8.61 \mathrm{e}-05$, jika terjadi peningkatan CAR sebesar 1 persen maka terjadi penurunan NPL yaitu sebesar 8.61e-05 persen

c) $\beta_{2}=-0.004049$, jika peningkatan LDR 1 persen maka terjadi penurunan NPL yaitu 0.004049 persen.

d) $\beta_{3}=0.003981$ artinya jika peningkatan NIM sebesar 1 persen maka terjadi peningkatan NPL yaitu 0.003981 persen

e) $\beta_{4}=-2.21 \mathrm{e}-05$ artinya jika peningkatan BOPO 1 persen maka terjadi penurunan NPL yaitu 2.21e-05 persen.

f) $\beta_{5}=0.116706$ artinya jika peningkatan bunga 1 persen maka terjadi peningkatan NPL yaitu 0.116706 persen.

g) $\beta_{6}=-0.210079$ artinya jika peningkatan inflasi 1 persen maka terjadi penurunan NPL yaitu 0.210079 persen.

\section{Pembahasan}

Hasil probabilitas F statistik menghasilkan nilai 0,0000 kurang dari $\alpha 0,05$ artinya CAR, LDR, NIM, BOPO, Bunga dan Inflasi secara simultan memiliki pengaruh signifikan terhadap NPL pada bank devisa di Indonesia. Nilai probabilitas $\mathrm{t}$ statistik variabel CAR adalah sebesar 0,8447 di atas $\alpha$ 
0,05 dengan nilai koefisien sebesar -8.61E05 . Nilai tersebut berarti bahwa variabel CAR secara parsial berpengaruh negatif tidak signifikan terhadap NPL pada bank devisa di Indonesia. Dalam hal ini H0 diterima dan H1 ditolak. CAR menunjukkan permodalan yang dimiliki oleh bank. Tingginya rasio CAR menunjukkan kemampuan permodalan bank yang semakin kuat sehingga lebih mampu dalam mengcover terjadinya risiko sehingga kredit bermasalah bank yang ditunjukkan dengan nilai NPL semakin kecil. Berdasarkan PBI Nomor : 15/2/PBI/2013, disebutkan bahwa bank wajib memiliki rasio kecukupan modal $8 \%$. Semakin tinggi nilai rasio CAR, maka semkain baik permodalan bank nya. Hasil penelitian yang tidak signifikan mengindikasikan bahwa besar kecilnya CAR tidak berpengaruh kepada jumlah kredit bermasalah bank karena setiap bank wajib memiliki rasio CAR sesuai dengan regulasi Bank Indonesia. Selama periode penelitian nilai CAR Bank Devisa sudah di atas $8 \%$. Hal ini mengindikasikan bahwa Bank Devisa sudah memenuhi ketentuan regulasi dari Bank Indonesia. Penelitian ini tidak mendukung penelitian Kamaludin, et al (2005) yang membuktikan CAR berpengaruh negatif signifikan terhadap NPL. Namun, penelitian ini mendukung penelitian Halim, Marisya (2015), Handayani dan Bambang (2017) yang membuktikan CAR tidak berpengaruh terhadap NPL.

Probabilitas $\mathrm{t}$ statistik variabel LDR adalah sebesar 0,2580 di atas $\alpha$ 0,05 dengan koefisien -0,004049 maka variabel LDR secara parsial berpengaruh negatif tidak signifikan terhadap NPL pada bank devisa di Indonesia. Kesimpulannya adalah $\mathrm{H} 0$ diterima dan $\mathrm{H} 2$ ditolak. LDR menunjukkan jumlah pinjaman yang diberikan kepada debitur. Ketidaksiginifikanan ini menunjukkan tinggi rendahnya kredit yang diberikan oleh bank tidak berpengaruh terhadap tinggi rendahnya kredit bermasalah bank yang ditunjukkan dengan rasio NPL. Peningkatan kredit pada bank tetap membutuhkan analisis yang tepat, pemantauan secara rutin serta pengelolaan kredit yang baik sehingga dapat menurunkan kredit bermasalah. Peningkatan kredit bank tanpa diimbangi dengan adanya pengelolaan kredit akan dapat meningkatkan risiko kredit bank. Kebijakan mengenai prinsip 6C (character, capacity, collateral, capital, constraint dan condition of economy) juga diterapkan oleh bank devisa dalam pemberian kredit. Penelitian ini tidak mendukung penelitian Halim, Marisya (2015) dimana LDR berpengaruh positif tidak signifikan terhadap NPL

Probabilitas t statistik NIM adalah sebesar 0,9367 di atas $\alpha$ 0,05 dengan koefisien 0,003981 maka variabel NIM secara parsial berpengaruh positif tidak signifikan terhadap NPL pada bank devisa di Indonesia. Kesimpulannya adalah H0 diterima dan $\mathrm{H} 3$ ditolak. Hasil penelitian ini mendukung penelitian Kamaludin, et al (2015), bahwa semakin tinggi NIM berarti penempatan aktiva produktif dalam bentuk kredit semakin efektif, sehingga kredit bermasalah semakin rendah dan NPL juga semakin rendah. Jika NIM menunjukan prosentase yang rendah, maka akan terjadi kenaikan kredit bermasalah dan NPL juga meningkat.

Probabilitas t statistik BOPO adalah 0,8359 di atas $\alpha 0,05$ dengan nilai koefisien 2.21E-05 maka variabel BOPO secara parsial berpengaruh negatif tidak signifikan terhadap NPL pada bank devisa di Indonesia. Kesimpulannya adalah $\mathrm{H} 0$ diterima dan $\mathrm{H} 4$ ditolak. Semakin kecil rasio BOPO maka beban operasional meningkat dengan prosentase yang lebih kecil dari prosentase peningkatan pendapatan operasional. Hal ini mengindikasikan efisiensi bank yang semakin baik. Bank yang semakin efisien dalam kegiatan operasionalnya maka bank akan semakin mampu menekan terjadinya kredit bermasalah. Akan tetapi selama periode penelitian terjadi peningkatan kredit bermasalah pada bank devisa yang ditunjukkan dengan rata-rata tren yang semakin meningkat.

Probabilitas t statistik tingkat suku bunga sebesar 0,0304 di bawah - $\alpha 0,05$ dan nilai koefisien sebesar 0.116706 maka variabel bunga secara parsial berpengaruh positif signifikan terhadap NPL pada bank devisa di Indonesia. Kesimpulannya adalah H0 ditolak dan H5 diterima. Secara teori peningkatan tingkat suku bunga bank yang dibebankan bank kepada debitur, dapat menyebabkan penurunan kemampuan membayar debitur dan menyebabkan 
semakin tinggi tunggakan kredit. Tingginya nilai tunggakan kredit dapat meningkatkan kredit bermasalah bank. Sepanjang tahun penelitian nilai NPL pada bank devisa di Indonesia mengalami peningkatan sebesar 0,02 persen. Hasil penelitian ini mendukung Skenderi, et al (2016) dan Pertiwi, Risna et al (2020) yang juga membuktikan suku bunga secara parsial berpengaruh berpengaruh positif signifikan terhadap NPL pada bank devisa di Indonesia. Dalam terhadap NPL.

Probabilitas $\mathrm{t}$ statistik inflasi 0,0000 di bawah 0.116706 dengan nilai koefisien sebesar -0.210079 maka variabel inflasi secara parsial berpengaruh negatif signifikan terhadap NPL pada bank devisa di Indonesia. Dalam hal ini H0 diterima dan H6 ditolak. Hal ini mengindikasikan penurunan tingkat inflasi dapat menyebabkan peningkatan kredit bermasalah. Rendahnya tingkat inflasi berarti semakin rendah tingkat bunga maka menyebabkan masyarakat akan lebih banyak mengajukan kredit. Inflasi yang semakin menurun menyebabkan kemampuan membayar debitur akan semakin membaik dan kredit bermasalah akan semakin menurun. Akan tetapi dalam masa penelitian nilai NPL pada bank devisa naik sebesar 0,02 persen. Peningkatan kebutuhan kredit yang tidak disertai dengan kemampuan membayar yang baik dari debitur akan menyebabkan peningkatan kredit bermasalah. Penelitian Iman Firmansyah (2014) membuktikan bahwa inflasi secara parsial berpengaruh negatif signifikan terhadap NPF pada bank syariah. Penelitian ini berbeda dengan Kamaludin, et al (2015) yang membuktikan inflasi berpengaruh positif tidak signifikan terhadap NPL. Halim, Marisya (2015) juga membuktikan tidak ada pengaruh antara inflasi dan NPL

\section{KESIMPULAN}

Secara simultan, terdapat pengaruh signifikan antara CAR, LDR, NIM, BOPO, bunga dan inflasi terhadap NPL pada bank devisa di Indonesia. Terdapat 3 variabel yang memberikan pengaruh negatif tidak signifikan terhadap NPL yaitu CAR, LDR dan BOPO. Hasil positif tidak signifikan terhadap NPL diperoleh dari variabel NIM. Variabel bunga memiliki pengaruh positif signifikan pada NPL, sedangkan variabel inflasi memiliki pengaruh negative yang signifikan pada bank devisa di Indonesia.

\section{REFERENSI}

Agustina, W dan A Surachim. 2017. Kredit Bermasalah untuk Meningkatkan Profitabilitas BUSN Non Devisa Go Public, Strategic.Jurnal Pendidikan Manajemen Bisnis, 17(1), 1-8.

Akbar, M Taufik., Moeljadi P \& Atim Djazuli. 2018. Pengaruh Kredit Macet Terhadap Profitabilitas Melalui Kecukupan Modal, Biaya dan Pendapatan Operasional.Jurnal Bisnis dan Manajemen, 5(1), 79-91.

Alexandri, Moh. Benny \& Teguh Iman Santoso. 2015. Non Performing Loan: Impact of Internal and External Factor (Evidence in Indonesia).International Journal of Humanities and Social Science Invention, 4(1), 87-91.

Andreani, C.B., dan Erick. 2016. Analisis Faktor-Faktor Yang Mempengaruhi Non Performing Loan pada Bank Umum di Indonesia. Jurnal Wira Ekonomi Mikroskil, 6(2), 113-122.

Astrini, Km Suli., I Wayan Suwendra \& I Ketut Suwarna. 2018. Pengaruh CAR, LDR, dan Bank Size Pada Lembaga Perbankan Yang Terdaftar di Bursa Efek Indonesia. Bisma: Jurnal Manajemen, 4(1), 2476-8782.

Bank Indonesia. 2005. Surat Edaran Bank Indonesia (SEBI) No 73/DPNP Tahun 2005 tentang Sistem Penilaian Kesehatan Bank Umum. www.bi.go.id.

Dwihandayani, Deasy. 2017. Analisis Kinerja Non Performing Loan (NPL) Perbankan di Indonesia dan FaktorFaktor Yang Mempengaruhi NPL. Jurnal Ilmiah Ekonomi Bisnis, 22(3), 265-274.

Fauzi, Achmad, Amor Marundha, Iwan Setyawan, Faroman Syarief, Raden Achma Harianto, Rachmat Pramukty. 2020. Analisis Capital Adequacy Ratio (CAR) dan Penilaian Tingkat Kesehatan Bank Pada PT Bank Syariah XXX. Jurnal Ilmiah Manajemen Bisnis dan Inovasi Universitas Sam Ratulangi, 7(1), 114127. 
Firmansyah, Irman. 2014. Determinant of Non Performing Loan: The Case of Islamic Bank in Indonesia.Buletin Ekonomi Moneter dan Perbankan, 17(2), 241-258.

Ginting, Join S Putra dan Mulyo A Haryanto. 2016. Pengaruh Capital Adequacy Ratio, Loan to Deposit Ratio, Loan Loss Provission dan Net Interest Margin Terhadap Non Performing Loan (Studi Kasus Pada Bank Umum Konvensional di Indonesia Yang Terdaftar di BEI pada Tahun 20082014. Diponegoro Journal of Management, 5(1), 1-7.

Halim, Marisya. 2015. Faktor Internal dan Faktor Eksternal yang Mempengaruhi Non Performing Loan di Bank Pemerintah dan Bank Swasta Jawa Timur Periode 2008-2012.Jurnal Ilmiah Mahasiswa Universitas Surabaya, 4(2), 1-20.

Handayani, Dewi Sri dan Bambang Sudiyatno. 2017. Kualitas Kredit Pada Industri Perbankan dan Dampaknya Terhadap Profitabilitas Bank (Studi Empirik pada Bank Umum Konvensional Yang Terdaftar di Bursa Efek Indonesia).Jurnal Bisnis dan Manajemen, 24(2),150-161.

Ikatan Bankir Indonesia. 2013. Memamahami Bisnis Bank. Jakarta: PT Gramedia Pustaka Utama.

Kamaludin., Darmansyah., Berto Usman. 2015. Determinan Non Performing Loan (NPL) pada Industri Perbankan (Bukti Empiris Perusahaan Go Publik di Bursa Efek Indonesia). Jurnal Aplikasi Manajemen, 13(4), 547-556.

Karim, Abdul dan Fifi Hanafia. (2020). Analisis CAR, BOPO, NPF, FDR, dan DPK Terhadap Profitabilitas (ROA) Pada Bank Syariah di Indonesia. Jurnal Manajemen dan Bisnis, 2(1), 36-46.

Linda, Muthia Roza., Megawati dan Deflinawati. 2015. Pengaruh Inflasi, Kurs dan Tingkat Suku Bunga
Terhadap Non Performing Loan pada PT. Bank Tabungan Negara (Persero), Tbk Cabang Padang. Journal of Economic and Economic Education, 3(2), 137-144.

Messai, A dan Jouini, F. 2013. Micro and Macro of Non Performing Loans.International Journal of Economics and Financial Issues, 4(3), 852-860.

Nuryanto dan Zulfikar Bagus Pambuko. 2018. Eviews Untuk Analisis Ekonometrika Dasar Aplikasi Dan Interpretasi. Magelang: Unimma Press.

Pertiwi, Risna Eka., Yusman Syaukat dan Dwi Rachmina. 2020. Faktor Yang Mempengaruhi Kredit Bermasalah Bank Konvensional dan Syariah di Indonesia. Jurnal Aplikasi Manajemen dan Bisnis, 6(1), 118-127.

Prihatin, Lilik., Albertus Sentot dan Pujiyono. 2018. Faktor Kredit Perbankan Bermasalah / Non Performing Loan. Jurnal Hukum dan Pembangunan, 6(1), 179-198.

Sugiyono. 2012. Metode Penelitian Bisnis. Bandung : Alfabeta.

Skenderi , N., Islami, X., Mulolli, E. 2016. The Influence of Macroeconomic Factors in The Failure of Returning The Bank Credits in Kosovo. Mediterranean Journal of Social Sciences, 7(1), 320-327.

Soedarsa, Herry Goenawan dan Apri Irianto Raharjo. 2015. Analisis Kredit Bermasalah Dan Penghapusan Kredit Bermasalah Terhadap Peningkatan Net Profit Margin (Studi Kasus Pada PT. Bank Rakyat Indonesia (Persero), Tbk Tahun 2011-2013). Jurnal Akuntansi dan Keuangan, 6(2), 125135.

Ulfa. 2017. Pengaruh Faktor Internal Debitur Terhadap Kredit Bermasalah pada PT Bank Negara Indonesia (Persero) Tbk Cabang Palu.Jurnal Katalogis, 5(9), 45-54. 